\title{
The Significance of Reserve Officer Training Unit Student as Part of Jawatankuasa Kolej Mahasiswa at Kolej Tun Dr. Ismail on The Reserve Officer Training Unit Student's Perspective
}

Mohd Noor Azli Ali Khan ${ }^{1 *}$, Aemi Syazwani Abdul Keyon ${ }^{2}$, Mohamad Arif

Mohamad Aminuddin ${ }^{3}$, Amirah Mahirah Razali', Mu'ammar Sirajuddin

Ibrahim $^{5}$

\begin{abstract}
${ }^{I}$ Azman Hashim International Business School, Universiti Teknologi Malaysia, 81310 UTM Johor Bahru, Johor, Malaysia,

${ }^{2}$ Department of Chemistry, Faculty of Science, Universiti Teknologi Malaysia, 81310 UTM Johor Bahru, Johor, Malaysia

${ }^{3}$ School of Civil Engineering, Faculty Engineering, Universiti Teknologi Malaysia, 81310 UTM Johor Bahru, Johor, Malaysia

${ }^{4}$ School of Computing, Faculty Engineering, Universiti Teknologi Malaysia, 81310 UTM Johor Bahru, Johor, Malaysia

${ }^{5}$ Institut Ibnu Sina, M02, Kolej Tun Dr Ismail, Universiti Teknologi Malaysia, 81310 UTM Johor Bahru, Johor, Malaysia,

*Corresponding Author Email: m-nazli@utm.my
\end{abstract}

\begin{abstract}
Reserve Officer Training Unit (ROTU) is a unit, training volunteer student which undergoes studies at undergraduate level to become a reserve officer. They will be commissioned as second lieutenants after completing the training. Thus, student committee known as Jawatankuasa Kolej Mahasiswa (JKM) is an association under residential college had been set up to conduct co-curricular activities outside the classroom for students. Besides, they are also intermediaries between students and campus management besides helping to manage students' welfare. More than half of JKM at Kolej Tun Dr. Ismail (KTDI) consisted with ROTU student. Active involvement outside the classroom has shown that apart of playing a critical role on student's soft skills, it also contributes huge impact toward academic performance. This study is conducted to determine the significance of ROTU student in JKM KTDI. The study conducted using questionnaire which involved 182 respondents of ROTU members, consisting of young officers and cadet. The set of questionnaire forms covered the respondents' backgrounds and questions regarding the importance of ROTU in the JKM association also included. The result produced the advantages for ROTU in JKM KTDI but there is several importance should be improved by both parties.
\end{abstract}

Keywords: Reserve Officer Training Unit, Jawatankuasa Kolej Mahasiswa, questionnaire, significant, students.

\section{INTRODUCTION}

The establishment of a defense team composed of university undergraduates is seen to be based on inspiration from the government for shaping the physical and mental well-being of citizens in the face of several forthcoming events. In its second line of strength, the concept of defense of a nation seen as a young warrior who ready to volunteer. As far as military theory is concerned, national defense cannot be depending on troops alone, because the voluntary back is also essential [1]. Thus, Reserve Officer Training Unit (ROTU) is a cooperation program between the Ministry of Defense and the Ministry of Education.

This ROTU program also supports the country and Institut Pengajian Tinggi Awam (IPTA) in developing disciplined quality and nurturing the good characteristics to make them more country-friendly, 
patriotic and nationalistic. This type of training program will build a favorable job culture among its employees in order to produce a quality, productive, innovative and creative primary and secondary job and to establish a powerful connection with the university in order to facilitate all matters relating to cadet training and administration [2]. Because of their fighting and endurance training, students who entered ROTU have the advantage over other students which can make them excellent in any sector they chose.

Indeed, co-curricular activities aimed at improving and enhancing student learning. The reason for this is that co-centered curriculum is a practice in which the know-how obtained through practical activities, whether in sport, association or uniform units. As a result, extra curriculum activity actually builds social dimensions as well as properties and psychomotor quality [3]. UTM has a student representative's committee known as Jawatankuasa Kolej Mahasiswa (JKM), for each residential college. JKM encourages the students in the aspects of growth, voluntary work, well-being, and provides platforms for learners to attend exciting activities and programs at a university. As well as civilian members of the JKM, ROTU is also encouraged to join the JKM because Kolej Tun Dr. Ismail (KTDI) is ROTU's main residential college and thus makes KTDI distinctive from other residential college.

The aim of this study is to emphasize how ROTU students are relevant in the ROTU perspective in the context of the JKM at KTDI. In this study, the ROTU represents a significant indicator because it will provide a basis for managing ROTU students in JKM. Besides that, it is a requirement to conduct this study in order to elaborate and assess a ROTU student's suitability for JKM representatives.

\section{LITERATURE REVIEW}

The ROTU training program is one of the most accessible curriculum courses at public universities in Malaysia, such as Universiti Teknologi Malaysia (UTM), Universiti Malaysia Perlis (UniMAP) and many more. The first battalion of the Royal Malaysian Army's Royal Malaysian Army offensive branch is a start of the early history of ROTU on 3 April 1965. The ROTU program supports government and IPTA's efforts to create the quality of a perfect, disciplined, and defenseless citizen as well as the development of reserve officials to satisfy the requirements of the Malaysian Armed Forces [3]. An officer trained on a part-time basis for a period of 3 years; regular training is provided each weekend covering military-related subjects. Moreover, further training and intensive training are also organized once a year for three weeks. Each branch of the ATM, the Army, Navy and Air Force are now included within ROTU program and every ROTU team has their own headquarters for the branch training. Up to this day, 18 publics and one private institution had formed ROTU program.

JKM was formed to conduct extra-curricular activities during the students' leisure time, to train them to be leading leaders, to strengthen the unity of all races, to build characters and to concentrate academic values on student work. Students need to provide advice on the characteristics of a leader and the welfare of society. That is why students emphasize the need for honesty and a sense of social responsibility in every elected or appointed leader [4].

The involvement of students in extracurricular activities is an excellent example of the world's best interaction [5]. The students who participate for extracurricular activities have also shown positive change in self-confidence, perception of the teachers, and greater trust in them and have subsequently developed a positive relationship to adults in the college. While, the aim of ROTU training is to develop students who can work in teamwork or spirited bodies [3]. Spirit of corps can be built when students are exposed to intense physical exercise requiring collective strength to face certain challenges. The task must be carried out with the assistance of a friend in a group.

Indirectly, the relationship between university and college can help the organization by gaining relevant knowledge between the two entities. In the end, this relationship can play an important role in building a bond for positive outcomes in cooperation between university and industry. In this study, ROTU and civilian in JKM may have different backgrounds in interpersonal and inter-organizational ties in order to create more excellence and programs through the exchange of ideas and knowledge.

\section{METHODOLOGY/MATERIALS}

This research used a quantitative research method. There are total of 203 respondents which were 22 respondents from young officers while another 181 respondents were from Reserve Officer Training Unit (ROTU) cadets to give their response on the relevance of the involvement of ROTU cadets in residential college management specifically in JKM in KTDI, UTM. There are three target respondents; i) JKM are referring to Students Representatives Committee, ii) ROTU cadets are referring to students that joins ROTU UTM, iii) JKM ROTU are referring to students who join both organizations which is Students Representatives Committee and ROTU UTM. Basically, this response collected using online questionnaire, Google Form and distributed to the targeted respondent through social media. This questionnaire was divided into three sections which were; i) Section A to obtain personal information of respondents, ii) Section B containing scaled-questions regarding on the correlation about JKM ROTU cadets and civilians and iii) section $\mathrm{C}$ containing open-ended queries from the opinion of respondents on the same theme. The information obtained then analyzed using descriptive method and presented in the chart of percentage. 


\section{RESULTS AND FINDINGS}

The results categorized into three sections; Section A, Section B and Section C. Section A summarized the assessment of the gender and academic performance or known as Cumulative Grade Point Average (CGPA) of the 22 respondents from young officers and 181 respondents from cadet. Section B comprised an analysis based on opinions of the respondents regarding to the relevance of JKM cadet in JKM KTDI then tabulated into percentage (\%). Section C presented the opinion of the respondents in an openended question which strongly related to the queries in previous section. From this response, an incorporate wise of judgement and decision can be justified.

\subsection{Section $A$}

Figure 1(left) shown the gender of respondents consisted with $51 \%$ of female and $49 \%$ of male. Gender is one of the factors to be considered when conducting a study based on opinion because different gender showed variety of perceptions. Meanwhile, for academic performance (Figure 1 - right), majority of the respondents have good performance with their CGPA ranging from 3.00 to 3.69. From total respondents, $22 \%$ of respondents have average CGPA of $2.70-2.99,10 \%$ of respondents have average CGPA of $2.00-2.70$ and $6 \%$ of respondents have average CGPA of $3.70-4.00$ which is in first class. From this result, we can conclude that, respondents involved with the organization able to balance their curricular and academic well.

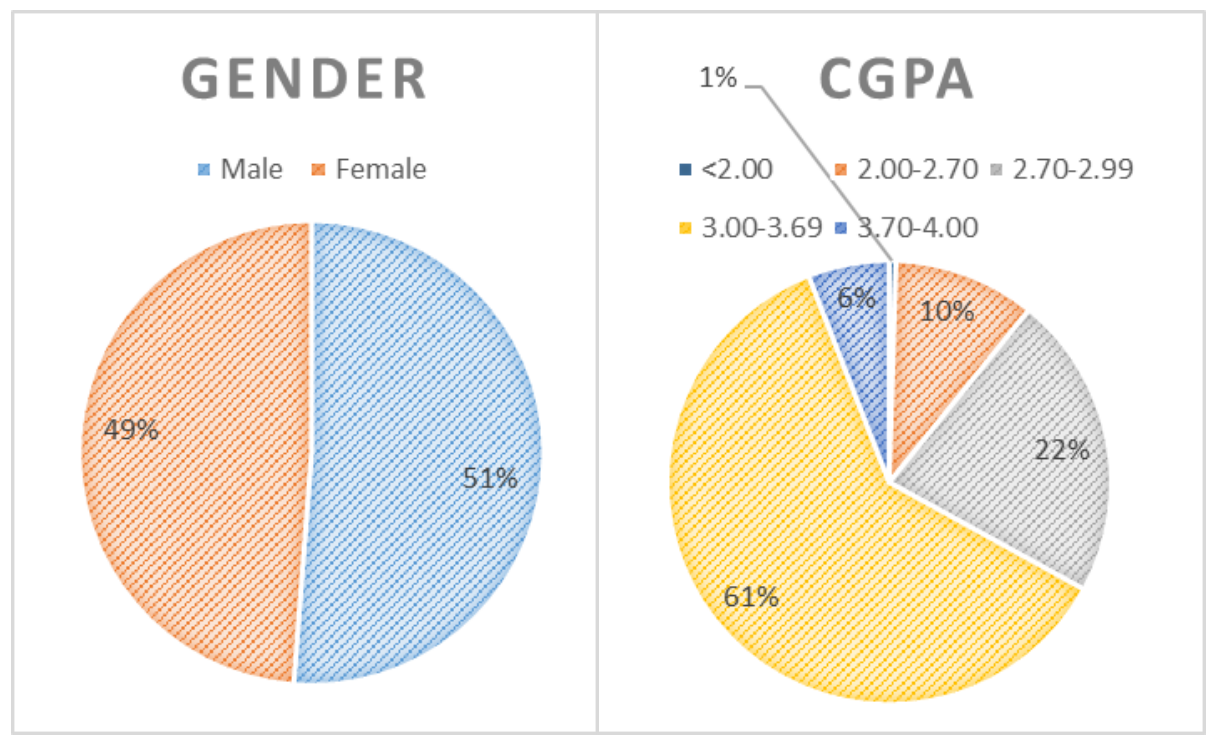

Figure 1 The distribution of respondents based on gender (left) and CGPA or known as academic performance (right).

Table 1 The findings regarding the correlation of ROTU cadets and young officers for 181 respondents and 22 respondents respectively, in percentage $(\%)$

\begin{tabular}{|c|c|c|c|c|c|c|}
\hline No. & Statements from cadet & $\begin{array}{l}\text { Strongly } \\
\text { Disagree }\end{array}$ & Disagree & Neutral & Agree & $\begin{array}{c}\text { Strongly } \\
\text { Agree }\end{array}$ \\
\hline 1. & $\begin{array}{l}\text { JKM ROTU cadet need to attend JKM } \\
\text { program even though there is } \\
\text { overlapping with their training. }\end{array}$ & $\begin{array}{c}10 \\
(6 \%)\end{array}$ & $\begin{array}{c}22 \\
(12 \%)\end{array}$ & $\begin{array}{c}72 \\
(40 \%)\end{array}$ & $\begin{array}{c}42 \\
(23 \%)\end{array}$ & $\begin{array}{c}35 \\
(19 \%)\end{array}$ \\
\hline 2. & $\begin{array}{l}\text { ROTU cadet necessarily involve as } \\
\text { higher council of JKM committee. }\end{array}$ & $\begin{array}{c}11 \\
(6 \%)\end{array}$ & $\begin{array}{c}11 \\
(6 \%)\end{array}$ & $\begin{array}{c}57 \\
(31 \%)\end{array}$ & $\begin{array}{c}52 \\
(29 \%)\end{array}$ & $\begin{array}{c}50 \\
(28 \%)\end{array}$ \\
\hline 3. & $\begin{array}{l}\text { The absence of JKM ROTU cadet in any } \\
\text { JKM-related program can be replaced by } \\
\text { other JKM committees. }\end{array}$ & $\begin{array}{c}4 \\
(2 \%)\end{array}$ & $\begin{array}{c}10 \\
(6 \%)\end{array}$ & $\begin{array}{c}62 \\
(34 \%)\end{array}$ & $\begin{array}{c}58 \\
(32 \%)\end{array}$ & $\begin{array}{c}47 \\
(26 \%)\end{array}$ \\
\hline 4. & $\begin{array}{l}\text { There is a social gap between ROTU } \\
\text { cadet and JKM ROTU cadet. }\end{array}$ & $\begin{array}{c}46 \\
(25 \%)\end{array}$ & $\begin{array}{c}40 \\
(22 \%)\end{array}$ & $\begin{array}{c}67 \\
(37 \%)\end{array}$ & $\begin{array}{c}17 \\
(9 \%)\end{array}$ & $\begin{array}{c}11 \\
(6 \%)\end{array}$ \\
\hline
\end{tabular}




\begin{tabular}{|c|c|c|c|c|c|c|}
\hline 5. & $\begin{array}{l}\text { It is easy to get manpower contribution } \\
\text { to run any program when there is } \\
\text { involvement of JKM ROTU cadet. }\end{array}$ & $\begin{array}{c}7 \\
(4 \%)\end{array}$ & $\begin{array}{c}9 \\
(5 \%)\end{array}$ & $\begin{array}{c}71 \\
(39 \%)\end{array}$ & $\begin{array}{c}66 \\
(36 \%)\end{array}$ & $\begin{array}{c}28 \\
(15 \%)\end{array}$ \\
\hline No. & Statements from young officer & $\begin{array}{l}\text { Strongly } \\
\text { Disagree }\end{array}$ & Disagree & Neutral & Agree & $\begin{array}{c}\text { Strongly } \\
\text { Agree }\end{array}$ \\
\hline 1. & $\begin{array}{l}\text { JKM ROTU cadet need to attend JKM } \\
\text { program even though there is } \\
\text { overlapping with their training. }\end{array}$ & $\begin{array}{c}9 \\
(41 \%)\end{array}$ & $\begin{array}{c}4 \\
(18 \%)\end{array}$ & $\begin{array}{c}3 \\
(14 \%)\end{array}$ & $\begin{array}{c}4 \\
(18 \%)\end{array}$ & $\begin{array}{c}2 \\
(9 \%)\end{array}$ \\
\hline 2. & $\begin{array}{l}\text { ROTU cadet necessarily involve as } \\
\text { higher council of JKM committee. }\end{array}$ & $\begin{array}{c}3 \\
(14 \%)\end{array}$ & $\begin{array}{c}2 \\
(9 \%)\end{array}$ & $\begin{array}{c}4 \\
(18 \%)\end{array}$ & $\begin{array}{c}4 \\
(18 \%)\end{array}$ & $\begin{array}{c}9 \\
(41 \%)\end{array}$ \\
\hline 3. & $\begin{array}{l}\text { The absence of JKM ROTU cadet in any } \\
\text { JKM-related program can be replaced by } \\
\text { other JKM committees. }\end{array}$ & $\begin{array}{c}1 \\
(5 \%)\end{array}$ & $\begin{array}{c}1 \\
(5 \%)\end{array}$ & $\begin{array}{c}5 \\
(23 \%)\end{array}$ & $\begin{array}{c}8 \\
(36 \%)\end{array}$ & $\begin{array}{c}7 \\
(32 \%)\end{array}$ \\
\hline
\end{tabular}

\subsection{Section B}

Table 1 shown the percentage of the respondents who participated in the study. Majority of cadet's respondent $(42 \%)$ agreed that JKM ROTU cadet need to attend JKM program even though there is redundancy with their training while $18 \%$ had disagreed with this statement. This is a contrary with the young officer where most of them $(59 \%)$ stated that cadet need to attend the training and $27 \%$ agreed with this statement. The highest percentage of cadet respondent agreed that ROTU cadets are needed as higher council in JKM committee is $57 \%$ while on the other hand, only $12 \%$ mentioned that there is no need for ROTU cadets to be in higher council. This statement had been supported by the young officer who mostly agreed by $59 \%$ and only $23 \%$ disagreed. If there is an overlapping between JKM program with cadet's training, $58 \%$ of cadet respondent agreed that JKM ROTU cadet can be replaced with any JKM members while $8 \%$ of the respondent disagreed with this statement. Once again, majority of young officer agreed with this statement by $68 \%$ while only $10 \%$ had disagreed that JKM ROTU cadets cannot be replaced in any JKM program.
There were two questions unanswered by young officer as it is not related to them. First question is, is there any social gap between ROTU cadet and JKM ROTU cadet and most of the respondent with $47 \%$ are saying that there is no social gap between ROTU JKM and ROTU cadets while $15 \%$ are saying that there is. Second question saying that it is easy to get manpower contribution to run any program when there is involvement of JKM ROTU cadet with $51 \%$ agreed with this question while $9 \%$ of cadet respondent were vice versa.

\subsection{Section $C$}

Figure 2, 3 and 4 shown the qualitative analyses on questionnaire to the target of research; the members of Reserve Officer Unit Training (ROTU) and nonmembers of ROTU known as civilians on the relevancy and the importance of ROTU cadets in one of the residential organization in UTM which in JKM at KTDI. This section of questionnaire provided was to obtain data from respondent based on open ended question to get the acceptable correlation and significance on the issues arose in JKM KTDI. JKM KTDI well known as the only residential college that strictly introduced the concept ration of $1: 1$ consists of both ROTU cadets and civilians. 


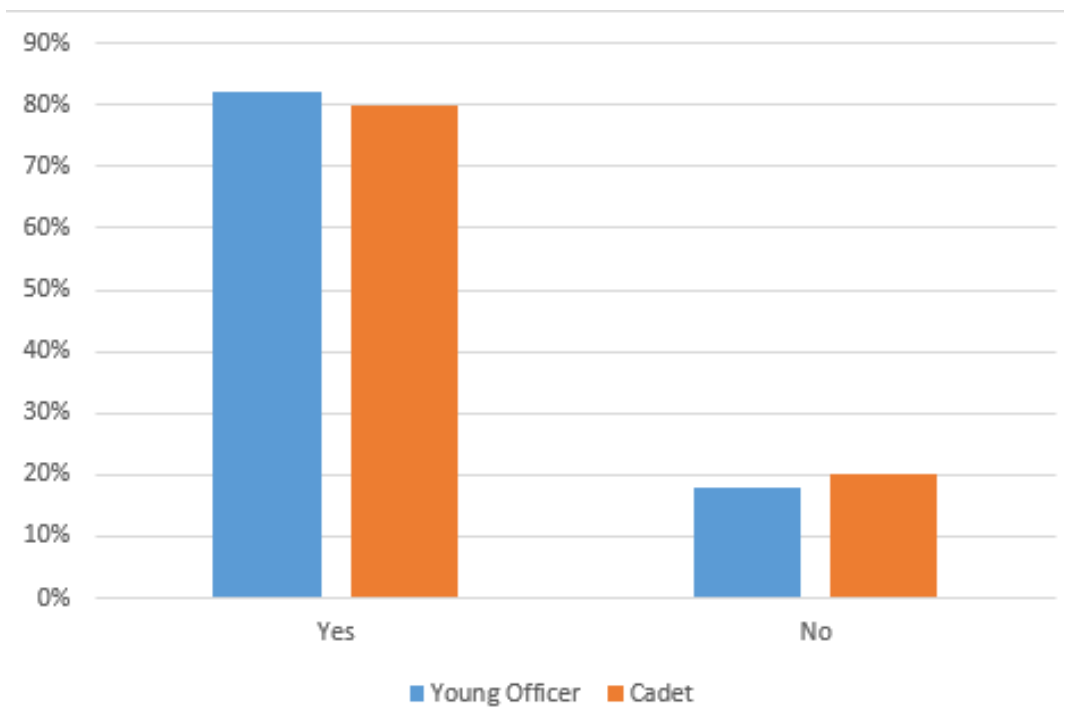

Figure 2 The result of open-ended answers on the needed of ROTU cadets be in KTDI

9 out of 22 respondents agreed that ROTU cadets should be in JKM KTDI as they believe that the welfare of ROTU cadets will be more secure.
Meanwhile, 46 out of 181 respondents agreed that ROTU cadets should be in JKM KTDI as the diversity of backgrounds and knowledge.

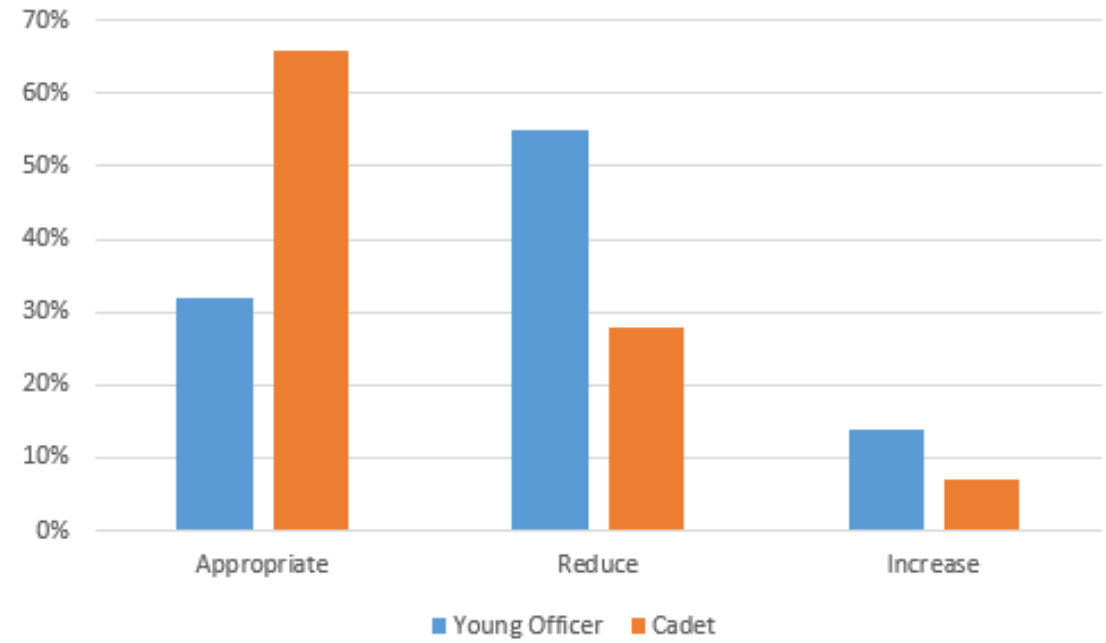

Figure 3 The result of the relevancy of ratio 1:1 between ROTU cadets and young officers. The answers should respond to the suitability on the ratio or should be reduced or should be increased.

Of the 22 respondents among the young officers, only 7 respondents said the ratio of ROTU 1: 1 member was appropriate to be given to JKM ROTU and nonJKM non-ROTU, 12 respondents said the ratio should be reduced as it could provide opportunities for nonROTU and 3 respondents said that the ratio should be increased to ensure that non-ROTU did not take over the administration of JKM KTDI easily and facilitate command and cooperation. Next question used to get the view on the suitability of ROTU cadet officer involvement in JKM KTDI. The finding from young officer's and from ROTU cadet's respondents, majority of $72 \%$ and $36 \%$ agreed that the involvement of ROTU cadets in JKM KTDI were relevant if it is at the will of the individual and no intervention from the authorities. In addition, ROTU in JKM KTDI represents as the identity of this college. 


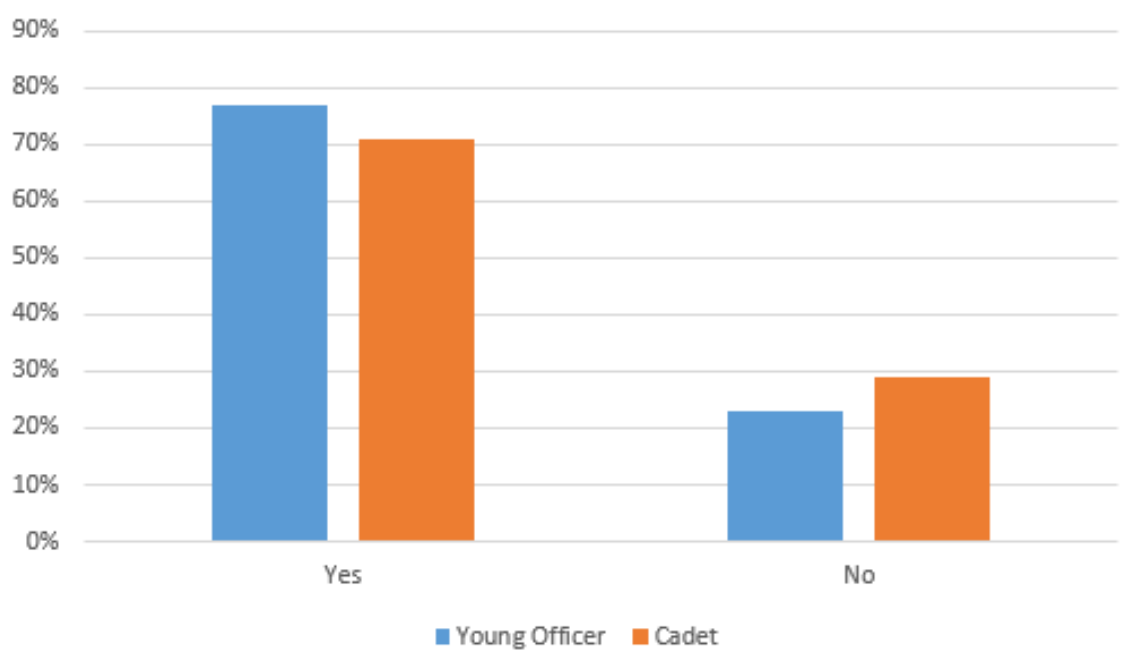

Figure 4 The result of the privilege of presidential position given to ROTU cadets.

KTDI well known as the only residential college with ROTU cadets and this uniqueness led to the privilege to them with the criteria based on his or her commitment, leadership, influence, personality and academic achievement. According to the finding as shown in Figure 3, $77 \%$ of young officer's respondents and $71 \%$ of cadet's respondents agreed with this continuity of the privilege of presidential position from ROTU cadets. Most agreed respondents believed that the involvement of ROTU cadets help the organization to be more discipline and easy to engage. Meanwhile, 23\% respondents from young officers and $29 \%$ respondents from cadets disagreed

\section{CONCLUSION}

Based on the findings from the respondents, ROTU cadet are still relevant in the organisation of JKM KTDI. As the identity of the college that houses ROTU student for 4 years, the ability and skill taught by ROTU to their students can be used as an advantage for JKM KTDI. Hence, the involvement of ROTU cadet in JKM KTDI are highly recommended. However, involvement of ROTU students should be on willingness and volunteerism without any coercion. The number of ROTU cadet should be reduced to give an opportunity for other students to join JKM as a platform for soft skill development. There is no social gap produced between ROTU cadet and JKM as they believe cooperation, improvement and learning a new thing should be their top priority. The objectives of this study have been fulfilled which JKM ROTU is still relevant in JKM KTDI. Also, this study is only limited to a certain respondent in UTM only but not the whole Malaysian academic institution. However, this study will put a benchmark on the relevance of ROTU students in JKM for an in-depth assessment in the future. Additionally, more parameters should be considered for other academic institutions including existing workload, preferences, ethnicity, geographical assessment, parenting history and more. Thus, a with this privilege of presidential college because for them, ROTU itself were packed with training schedule but it was an opportunity for civilians to make themselves as true leader or as a president.

Last assessment on the questions regarded to the action of a ROTU cadet in JKM with the statement of "the presence of ROTU cadets on training day is a MUST". A majority of $77 \%$ of respondents from young officers and $50 \%$ of cadets agreed that if any cadet was involved in a non-ROTU program, they would need to provide a letter of release from ROTU UTM as black and white evidence.

comprehensive result may be presented to fill in all the research gaps found in this study.

\section{ACKNOWLEDGMENT}

We would like to thank Kolej Tun Dr. Ismail (KTDI) and Universiti Teknologi Malaysia

(UTM) for the financial support.

\section{REFERENCES}

[1]Fazurawati Che Lah, "PALAPES bentuk jati diri | Harian Metro," 2018, 2018.

[2]N. S. Md Yusof, Q. B. Mohd Yusof, and R. Abbas, "The Implementation Of Military Leadership Training Programme; Reserve Officer Training Unit (Rotu) In Shaping Islamic Moral Among Cadets: A Study In Universiti Sains Islam Malaysia (USIM)," 2017.

[3]M. Hashim, "The Advantages of Reserve Officer Training Unit (ROTU)'s Activities to Future TVET Teachers," Asian Res. J. Arts Soc. Sci., vol. 1, no. 3, pp. 1-8, Jan. 2016.

[4]A. Ganti, "Social Responsibility Definition," 2019. 
[5]S. Mancha and A. Ahmad, "Co-Curricular Activities And Its Effect On Social Skills," Int. Conf. Educ. Reg. Dev. 2016, 2016. 